\title{
WALKING TOWARD IPSAS ADOPTION: A DISCUSSION ABOUT BRAZILIAN PUBLIC SECTOR CHANGES UNDER THE PERSPECTIVE OF INSTITUTIONAL THEORY
}

\author{
CAMINHANDO PARA A ADOÇÃO DA IPSAS: UMA DISCUSSÃO SOBRE AS \\ MUDANÇAS DO SETOR PÚBLICO BRASILEIRO SOB A PERSPECTIVA DA TEORIA \\ INSTITUCIONAL ${ }^{1}$
}

\begin{tabular}{|l|r|} 
Recebido: 15/08/2019 - Aprovado: 12/12/2019 - Publicado: 02/01/2020 João Gabriel Nascimento de Araújo ${ }^{2}$ \\
Processo de Avaliacáa: Double Blind Review
\end{tabular} ABSTRACT

This study who aims to examine the influences of institutional forces on the process of convergence in governmental accounting in Brazil. Beside de introduction, the second section outlines the adoption of IPSAS in Brazil. In the third part, we approach, from the institutional theory NIS point of view, specific from the mimetic, normative and coercive pressures, this process of change in Brazilian government accounting; and finally, we made some final considerations on the subject. We discuss some real cases of Brazilian context on IPSAS adoption, based on direct observation, several informal interviews with different agents on Brazilian's public sector in different levels and various institutions and literature review. Is important point that the examples showed here are not and do not pretend to be exhausted, but only illustrative. Our intention is foment the debate and clarify some institutional pressures who exists in this process. We suggest as next steps could be to examine qualitative factors such as: the quality of the financial statements; impact on wider management practices (are budgets based on accruals, the use of the balance sheet to inform decision making, etc.); and whether external stakeholders (citizens, elected members, societal groups, etc.) consider that the introduction of IPSAS has improved accountability.

Keywords: Institutional Theory. NIS. Brazilian Public Sector. Changes in Public Sector.

\begin{abstract}
RESUMO
Este estudo tem como objetivo examinar as influências de forças institucionais no processo de convergência em contabilidade governamental no Brasil. Além da introdução, a segunda seção descreve a adoção das IPSAS no Brasil. Na terceira parte, abordamos, do ponto de vista da teoria institucional do NIS, específico das pressões miméticas, normativas e coercitivas, esse processo de mudança na contabilidade do governo brasileiro; e, finalmente, fizemos algumas considerações finais sobre o assunto. Discutimos alguns casos reais do contexto brasileiro sobre a adoção das IPSAS, com base em observação direta, várias entrevistas informais com diferentes agentes do setor público brasileiro em diferentes niveis e várias instituições e revisão de literatura. É importante ressaltar que os exemplos mostrados aqui não são e não pretendem estar esgotados, mas apenas ilustrativos. Nossa intenção é fomentar o debate e esclarecer algumas pressões institucionais que existem nesse processo. Sugerimos como próximos passos o exame de fatores qualitativos, tais como: a qualidade das demonstrações contábeis; impacto em
\end{abstract}

\footnotetext{
1 Apresentado no CONBCON - Congresso Online Brasileiro de Contabilidade 2019: https://conbcon.com.br/academico/resultados/walking-toward-ipsas-adoption-a-discussion-about-brazilianpublic-sector-changes-under-the-perspective-of-institutional-theory/072b030ba126b2f4b2374f342be9ed44

2 Doutorando em Ciências Contábeis pela Universidade Federal de Pernambuco (UFPE). Brasil. j_gabrie190@hotmail.com

${ }^{3}$ Doutor em Contabilidade pela Universidad de Zaragoza. Professor da Universidade Federal de Pernambuco (UFPE) Brasil. caspufpe@gmail.com
} 
práticas de gerenciamento mais amplas (são orçamentos baseados em acréscimos, uso do balanço patrimonial para informar a tomada de decisão, etc.); e se as partes interessadas externas (cidadãos, membros eleitos, grupos sociais etc.) consideram que a introdução das IPSAS melhorou a prestação de contas.

Palavras-chave: Teoria Institucional. NIS. Setor Público Brasileiro. Mudanças no setor público.

\section{INTRODUCTION}

Many factors influence the process of change in the Brazilian public sector. The approach adopted by Brazil - e.g. introducing financial reporting standards through a statutory accounting code - is common. This is the approach adopted in the UK, NATO and the by the EU for its internal administration. In this paper we highlight about some specific consequences of the IPSAS adoption in Brazilian case.

The process of convergence of international standards of public accounting in Brazil begins in 2008, with the inclusion of the public sector in the Brazilian convergence committee. In addition, the federal government has a great influence in this process by issuing laws and presenting the Public Sector Accounting Manual (MCASP).

This process occurs since the 1980s in many countries (Yamamoto \& Noguchi, 2013) and made progress in converting the governmental account from cash-based to accrual-based (Olson, Guthrie \& Humphrey, 1998; Jackson \& Lapsley, 2003; Khan \& Mayes, 2009). It changes is justified by the adoption of the new public management (NPM), which, according Hood (1991) is the synthesis of institutional economics and management thought.

Despites the relative antiquity of the convergence, research on this theme is recent. On this, Pollitt (2002) points that the motivations and implications vary depending on specifics contexts. Sargiacomo \& Gomes (2011) pointed that the feel studies on the theme are biased in consequence of a disproportionately research in Anglophone scenarios. The authors add that the practices in Anglophone and non-Anglophone contexts have significant differences.

While explaining public sector accounting reforms, recently studies adopt the New Institutional Sociology (NIS) (DiMaggio \& Powell 1983, 1991) or Positive Accounting Theory (PAT) (Zimmerman, 1977; Watts \& Zimmerman, 1979). In this paper we choose the NIS because we understand that is more appropriate to explain the pressures, by the point of view of sociopolitical and economics nexus, in Brazilian's convergence process in public sector. 
Based on what Weber (1978) defined as the bureaucratization stemming from the capitalist market economy, which he called the "iron cage," DiMaggio \& Powell (1983) argue that, once a group emerges as a field, rational actors make their organizations more similar, through an isomorphism process. In this sense, Meyer \& Rowan (1977) affirm that this ismorphism seeks more legitimacy than an improvement of performance.

DiMaggio \& Powell (1983) then define three types of isomorphism: coercive, mimetic and normative. Coercive isomorphism results both from formal and informal pressures exerted on organizations by other organizations on which they depend. In turn, mimetic isomorphism results from uncertainty environments, where organizations copy models, when the environment does not provide clear answers. The third source of isomorphic changes, the normative, derives mainly from the professionalization, that is, the force exerted by a certain profession in the work environment.

In this context, examining the environmental factors affecting the IPSAS adoption decision for a sample of 110 countries, Sellami and Gafsi (2019) found a positive influence of external public funding (coercive isomorphic pressure), the degree of external openness (mimetic isomorphic pressure), and the importance of public sector organizations on countries decision to adopt IPSAS.

On this way, some studies also examines changing process in governmental accounting in European countries (Sargiacomo \& Gomes 2011; Ryan, 1998; Mattison, Näsi \& Tagesson, 2004; Lande, 2006; ter Bogt; 2008), Australia (Ryan, Guthrie \& Day, 2007), Japan (Yamamoto $\&$ Noguchi, 2013) and the USA (Carpenter \& Feroz, 2001).

On the other hand, just feel papers board non-Anglophone countries (Yamamoto \& Noguchi, 2013) and, especially on South America. Analyzing Colombia and Peru, Brusca, Gómez-Villegas \& Montesinos (2016) indicate that the IPSAS adoption is still a goal and the convergence process to IPSAS can be observed through the institutional theory as a process of isomorphism in which the IPSAS application is more rhetorical than practical, due to the fact that the financial statements are not being used in decision-making process in government entities yet.

In Brazilian case, some studies indicate the progress and some differences between Brazilian federation entities on the adoption of the Brazilian Public Sector Accounting 
Standards from the convergence process to IPSAS in specifics cities and states (Amorim \& Marques, 2019; Couto \& Moraes, 2019; Castro, 2016).

Our position on this paper is that exists particular institutional pressures on Brazilian's IPSAS adoption (and in the convergence process). Throughout the text, we will defend this point of view, better clarifying our view on the subject.

Given this background, and the expressive influence of Brazil in the continent, it justifies this study who aims to examine the influences of institutional forces on the process of convergence in governmental accounting in Brazil.

This paper is organized in four sections. In addition, the second section outlines the adoption of IPSAS in Brazil. In the third part, we approach, from NIS point of view, this process of change in Brazilian government accounting; and finally, we made some final considerations on the subject

\section{THE ADOPTION OF IPSAS IN BRAZIL}

The internationalization of public accounting began with the creation of the International Federation of Accountants (IFAC) in 1977. This institution was created with the purpose of strengthening public sector accounting worldwide, developing high-quality accounting standards, for the proper adoption and application thereof. (Nascimento, 2007; Salaroli, Almeida \& Gama, 2015).

The International Public Sector Accounting Standards Board (IPSASB) is an IFAC committee, which is an international, non-profit entity responsible for the development of IPSAS, providing guidance and resources for its use in public entities around the world in the preparation of its financial statements.

The process of elaboration of IPSAS counts on the contribution of various entities and actors (participating agents) around the world, in a democratic method that opens the opportunity for interested parties to improve the standards made available for public consultation. The IPSAS proposal, issued by the IPSASB, is available on the Internet as a draft called Exposure Draft (ED), for receiving comments letters. After this moment, IPSASB filters and analyzes the suggestions that can be accepted or not, as long as it contributes to an international public accounting standard (IFAC, 2019). 
According to Bezerra Filho (2016), Brazilian public accounting goes through a moment of effective structural renovation and indispensable updating. The focus on public equity, the transparency of information as an inducer of controls and the need for convergence with IFAC's international standards are the central vectors of this challenge.

The process of change began with the publication of the Brazilian's boards of governmental accounting (NBC TSP) and the inclusion of the public area in the Brazilian Convergence Committee in 2008. The Federal Government also made a great contribution, especially with the Ministerial Order of the Ministry of Finance 184/2008, Decree 6976 / 2009, the National Treasury Secretariat Ordinance 548/2015 and the MCASP, which established the new chart of accounts (PCASP) to be applied in the accounts of all Brazilian public administration bodies, improving the current Financial Statements Applied to the Public Sector (DCASP), provided for in Federal Law 4320/1964, and inserting others, such as: the Statement of Cash Flow and the Statement of Changes in Shareholders' Equity.

On this way, Botinha (2018) found that the perceived quality of accounting was pointed out as being one of the determinants in the reduction of perceived corruption, and Chan (2010) indicated that International Public Sector Accounting Standards (IPSAS) could be considered as a tool to combat corruption in developing countries, because unless integrity is assured in financial information, the credibility of government financial information is threatened.

\section{A INSTITUTIONAL VIEW OF THE PROCESS OF ADOPTION OF IPSAS IN BRAZIL}

As pointed by many studies (Hood, 1995; Groot \& Budding, 2008; McGregor, 1999; Micallef \& Peirson, 1997; Yamamoto \& Noguchi, 2013) since the 1980s many countries have initiated public sector reforms, supported by New Public Management (NPM) adoption, with the objective of improving public sector efficiency with the adoption of accrual accounting being a prominent feature.

Guthrie (1998) suggested that the perceived "self-evident" link created between accrual accounting and efficiency becomes from the large adoption by many OECD countries. In this context, we can suppose that a coercive pressure forced developing countries to adopt such practices. Miller (1994) pointed that this establish much more legitimacy in international context than improve efficiency. This position was enforced by Ahn, Jacobs, Lim \& Moon 
(2014) and Yamamoto \& Noguchi (2013), who studies the adoption of accrual based accounting, respectively, in South Korea and Japan.

However, especially academics have taken a much more critical approach towards the introduction of accrual accounting than the advocacy and development agency and regulators. It suggests that these adoption are consequences of coercive pressures than provide significant change in internal management (Hoque, 2005).

\section{INSTITUTIONAL CHANGES IN DIFFERENT LEVELS OF BRAZILIAN CONTEXT}

In this section, we discuss some real cases of Brazilian context on IPSAS adoption, based on direct observation, several informal interviews with different agents on Brazilian's public sector in different levels and various institutions and literature review.

Is important point that the examples showed here are not and do not pretend to be exhausted, but only illustrative. Our intention is foment the debate and clarify some institutional pressures which exists in this process.

We start point that each level, each institution sphere, has different structure, which means that, for example, the armed forces (linked to the federal sphere) can develop a system of costs and in the same region, cities (municipal sphere) cannot even control their own budget. These differences are decisive for the adoption of the standard. The difference between different spheres of government lead to different levels of adoption and consequently information useful only to those that are in the condition of federal or state entities and their equivalents.

To illustrate, while the municipalities of the state of Paraíba suffer from the insufficiency of basic public management tools (Santana, 2008), the Fire Department of the same state (state sphere) has already been able to implement a Balanced Scorecard (BSC). Another example is the results of the analysis of the adoption of IPSAS in the Brazilian states (Sasso, Souza \& Varela, 2019) who shows that the states of nation are in several different stages of adoption.

Starting from the mimetic pressures, we have the adoption of management software in public entities. Moreover, we can cite the case of Brazilian federal universities: by management option, most universities adopt the same integrated system of patrimony, administration and 
contracts (SIPAC), which was developed by the Federal University of Rio Grande do Norte (UFRN).

Identified pressures resulting from education and class and professional organizations, normative pressures, are derived, for example, the Court of Auditors, which promotes a few times a year the Accounting and Fiscal Week for States and Municipalities (SECOFEM), whose discussions and trainings are directed at the public servants and managers of the state and municipal spheres.

Another regulatory pressure concerns the outsourcing of accounting services. Small municipalities and public bodies can (and do), for lack of structure and resources, accounting through outsourcing, that is, hiring some private office to execute the accounting part. Often the same office takes over the accounts of dozens of counties. This many times creates a lack of connection between management procedures and day-to-day entities, since accounting is only performed to comply with a rule, but it is not institutionalized.

In accounting education, we also find normative pressures. The international norms in the private sector were and still are widely diffused in the graduation in accounting, including the appearance of a discipline called "international accounting" in several curricular grades that in the last decades brings new concepts and new procedures that are being adopted.

On the other hand, the public sector, in addition to having a few disciplines in the curricular grades on accounting degree (often only two or three 60-hour courses), does not have a specific one on international standards - which leads to a difference between the standards and the valuation of public accounting in the Brazilian context.

This view is reinforced by the work of the Federal Accounting Council (CFC), which requires approval in a test to perform the function of accountant, called the Examination of Sufficiency. This test is applied in this format since 2011, twice a year, containing 50 questions, which requires the minimum set of 25 questions to be considered fit to practice the profession. However, historically, only 2 are about public accounting, demonstrating some disinterest in the class organization in which the accountant understands the minimum about accounting applied to the public sector and its changes.

In order to have an idea, to perform the function of external auditor or forensic accountant, the professional must submit to another specific test, also elaborated by the CFC, which does not occur in the case of accounting professionals in the public sector. 
As example of coercive pressure, we can cite the most of the changes who occurs. A coercive logic exists in Brazilian courts of law, which are influenced by the higher courts. In the case of the Superior Electoral Court, it requires a copy of behavior that influences the regional electoral courts through rules and conduits for expenses and accounting procedures, execution and in the accounting context.

This pressure also exists on the part of the states and municipalities that most depend on federal government transfers. These transfers, defined by the Brazilian Federal Constitution, are called the Federal and State Participation Funds (FPE) and Municipal Participation Funds (FPM). The more dependent on the state or county is these funds, i.e. the less own revenue the entity has, the more it needs to adapt the rules and behaviors required by the union to receive the feature.

Perhaps the most coercive pressure comes from external controls. The Brazilian Federal Constitution prohibits public entities from being audited by private companies. In this sense, the Court of Auditors and other control bodies, trained by their own schools, are gaining strength, which dictate the degree of adoption within what will be required and what is expected to be applied. Thus, if the aforementioned federal universities adopt their management software by mimicry, before that choice there was a technical opinion from a Court of Auditors that recommended the use of this type of management tool.

In addition, the National Treasury Secretariat (STN) has implemented the Patrimonial Accounting Procedures Implementation Plan (PIPCP), which establishes a series of deadlines for the adoption of certain accounting procedures for the different spheres of power.

\section{CLOSING COMMENTS}

This work sought to approach the adoption of IPSAS in the Brazilian context, supported by several practical situations, with support in institutional theory.

Our intention was not to exhaust the subject or to approach it in depth of case studies, but rather to bring to light the debate of the changes that have occurred in the Brazilian public sector since 2008 , with a look at the pressures in these processes.

We consider the central aspect of this paper to demonstrate that, in general, different actors such as class councils, court of accounts, national treasury secretariat and universities represent important sources of pressures to influence changes in the adoption of IPSAS in the 
Brazilian context. Even in smaller structures, such as the municipalities of a state, it is possible to observe the action of institutional pressures. In this way, we strongly suggest the study of these relations to explain specific phenomena that lead to implementation.

We suggest as next steps could be to examine qualitative factors such as: the quality of the financial statements; impact on wider management practices (are budgets based on accruals, the use of the balance sheet to inform decision making, etc.); and whether external stakeholders (citizens, elected members, societal groups, etc.) consider that the introduction of IPSAS has improved accountability.

\section{REFERENCES}

Ahn, P. D., Jacobs, K., Lim, D. W., \& Moon, K. (2014). Beyond Self-Evident: Recognising the Problematic Political Context of Accrual Accounting Adoption in South Korea. Financial Accountability \& Management, 30(1), 25-48.

Amorim, D. A., \& Marques, A. V. C. (2019). O estágio da convergência às normas internacionais de contabilidade aplicadas ao setor público na administração direta do município de Monte Carmelo-MG. Revista de Auditoria Governança e Contabilidade,7(28), 1-16.

Bezerra Filho, J. E. (2016). Contabilidade Aplicada ao Setor Público-Abordagem simples e objetiva. Revista Brasileira de Contabilidade, (220), 90-90.

Botinha, R. A. (2018). A corrupção e o ambiente contábil dos países. (Tese de Doutorado). Universidade Federal de Uberlândia.

Carpenter VL \& Feroz EH (2001) Institutional theory and accounting rule choice: An analysis of four US state governments' decisions to adopt generally accepted accounting principles. Accounting, Organizations and Society 26(7/8): 565-596

Castro, M. C. C. S. (2016). Convergência das Normas Brasileiras de Contabilidade Aplicadas ao Setor Público aos padrões internacionais: análise da evidenciação pelos estados brasileiros e pelo Distrito Federal. Master's Dissertation, Faculdade de Ciências Econômicas, Universidade Federal de Minas Gerais, Belo Horizonte.

Couto, L. H. N., \& Moraes, E. F. de (2019). Processo de convergência da contabilidade pública: um enfoque na divulgação do balanço patrimonial dos estados do nordeste. Brazilian Journal of Development, 5(1), 118-139.

Chan, J. L. (2010). As NICSPS e a contabilidade governamental de países em desenvolvimento. Revista de Educação e Pesquisa em Contabilidade, 4(1), 1-17.

DiMaggio PJ \& Powell WW (1983) The iron cage revisited: Institutional isomorphism and collective rationality in organizational fields. American Sociological Review 48(2): 147-160.

DiMaggio PJ \& Powell WW (1991) Introduction. In: Powell WW and DiMaggio PJ (eds) The New Institutionalism in Organizational Analysis. Chicago: University of Chicago Press, pp.133. 
Groot, T., \& Budding, T. (2008). New public management's current issues and future prospects. Financial Accountability \& Management, 24(1), 1-13.

Guthrie, J. (1998). Application of accrual accounting in the Australian public sector-rhetoric or reality. Financial accountability \& management, 14(1), 1-19.

Hood C (1991) A public management for all seasons? Public Administration 69(1): 3-19.

Hood, C. (1995). The "new public management" in the 1980s: Variations on a theme. Accounting, organizations and society, 20(2-3), 93-109.

Hoque, Z. (2005). Securing institutional legitimacy or organizational effectiveness? A case examining the impact of public sector reform initiatives in an Australian local authority. International Journal of Public Sector Management, 18(4), 367-382.

IFAC - International Federation of Accountants, 2019. Disponível em $<$ http://www.ifac.org $>$ Acesso em 17 jan. 2019.

Jackson, A \& Lapsley, I (2003) The diffusion of accounting practices in the new "managerial" public sector. The International Journal of Public Sector Management 16(4/5): 359-372.

Khan A \& Mayes S (2009) Transition to Accrual Accounting. Washington DC: IMF.

Lande E (2006) Accrual accounting in the public sector: Between institutional competitiveness and the search for legitimacy. In: Lande E and Scheid JC (eds) Accounting Reform in the Public Sector: Mimicry, Fad or Necessity. Paris: Experts Comptables Media

Mattisson O, Näsi S and Tagesson T (2004) Accounting innovations in the public sector. In: 27th Annual Congress of the European Accounting Associations. Prague.

McGregor, W (1999). The pivotal role of accounting concepts in the development of public sector accounting standards. Australian Accounting Review, 9(17), 3-8.

Meyer, J. W., \& Rowan, B. (1977). Institutionalized organizations: Formal structure as myth and ceremony. American journal of sociology, 83(2), 340-363.

Micallef, F., \& Peirson, G. (1997). Financial reporting of cultural, heritage, scientific and community collections. Australian Accounting Review, 7(13), 31-37.

Miller, P. (1994). Accounting as social and institutional practice: an introduction. Accounting as social and institutional practice, 1, 20.

Nascimento, L. S. D. (2007). A reforma da contabilidade governamental brasileira: a necessária revisão dos preceitos vigentes em face das demandas de informações e do esforço de harmonização nacional e internacional. Brasília: Esaf, 79.

Olson O, Guthrie J \& Humphrey C (1998) Global Warning: Debating International Developments in New Public Financial Management. Oslo: Cappelen Akademisk Forlag.

Pollitt, C (2002) Clarifying convergence: Striking similarities and durable differences in public management reform. Public Management Review 4(1): 471-492.

Ryan C (1998) The introduction of accrual reporting policy in the Australian public sector: An agenda setting explanation. Accounting, Auditing \& Accountability Journal 11(5): 518-539.

Ryan C, Guthrie J and Day R (2007) Politics of financial reporting and the consequences for the public sector. Abacus 43(4): 474-487. 
Salaroli, A. R., de Almeida, J. E. F., \& Gama, J. R. (2015). A participação de entes internacionais no processo de consulta pública da norma contábil pública internacional sobre ativos intangíveis. Revista Ambiente Contábil, 7(2), 153-170.

Santana, Ed Wilson Fernandes de. (2008). A utilização da informação contábil como um instrumento de controle social dos municípios paraibanos com mais de 50.000 habitantes. 2008 . 122 f., il. Dissertação (Mestrado em Ciências Contábeis)-Programa Multiinstitucional e InterRegional de Pós- Graduação em Ciências Contábeis, Universidade de Brasília/UFPB/UFRN, João Pessoa.

Sargiacomo M \& Gomes D (2011) Accounting and accountability in local government: Contributions from accounting history research. Accounting History 16(3): 253-290.

Sellami, Y. M., \& Gafsi, Y. (2019). Institutional and economic factors affecting the adoption of International Public Sector Accounting Standards. International Journal of Public Administration, 42(2), 119-131.

Ter Bogt HJ (2008) Management accounting change and new public management in local government: A reassessment of ambitions and results - an institutionalist approach to accounting change in the Dutch public sector. Financial Accountability and Management 24(3): 209-241.

Watts RL \& Zimmerman JL (1979) The demand for and supply of accounting theories: The market for excuses. The Accounting Review 54(2): 273-305

WEBER, Max. Economy and society: An outline of interpretive sociology. Univ of California Press, 1978.

Yamamoto, K., \& Noguchi, M. (2013). Different scenarios for accounting reform in nonAnglophone contexts: The case of Japanese local governments since the 1990s. Accounting History, 18(4), 529-549.

Zimmerman JL (1977) The municipal accounting maze: An analysis of political incentives. Journal of Accounting Research 15: 107-144. 